\title{
Livros: a cada página um universo se abre
}

DOI: dx.doi.org/10.18616/nrm04

Gabriel Muffato Luciane Bisognin Ceretta Renan Antônio Ceretta

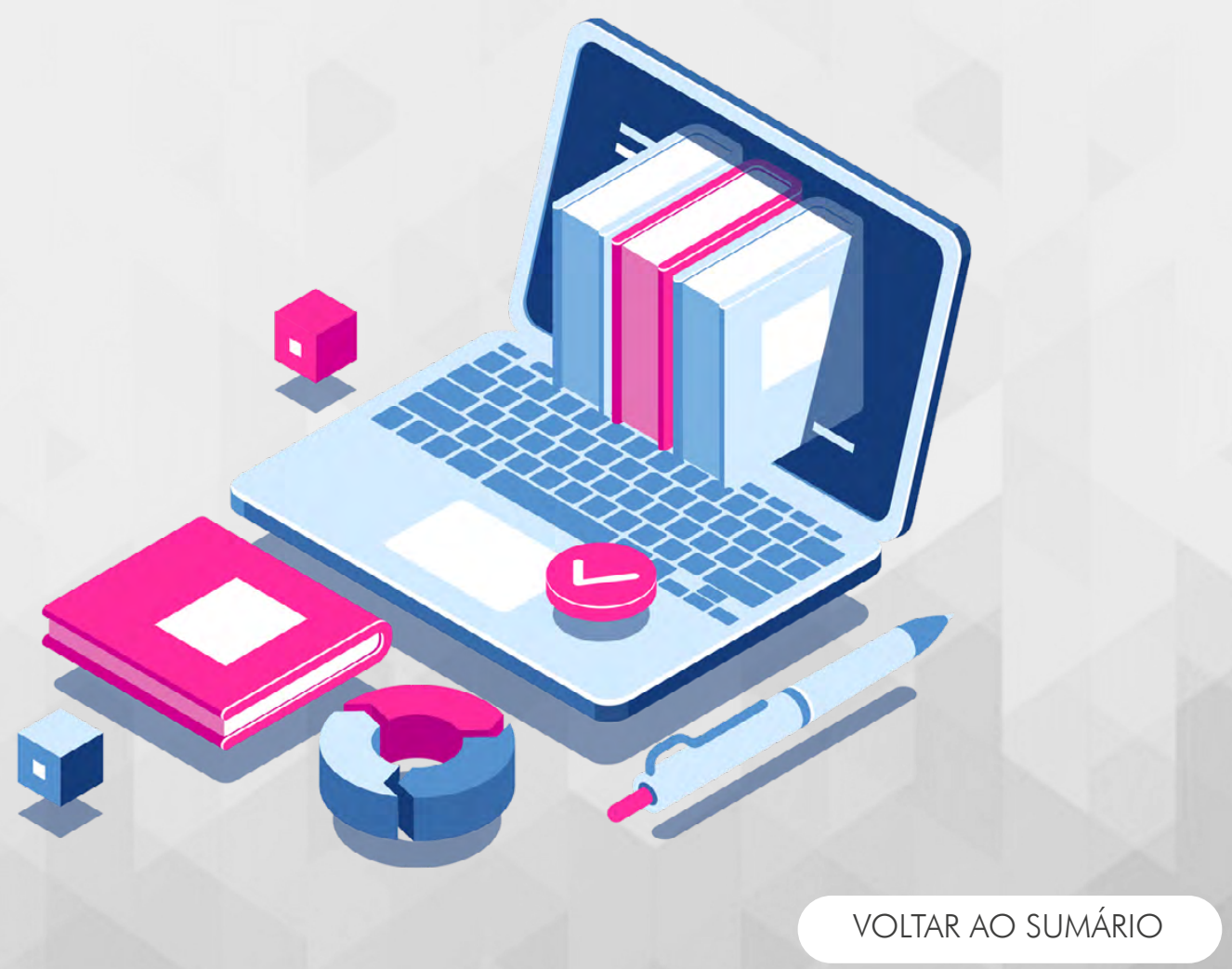


A leitura oportuniza explorar nossa imaginação dentro das histórias e as personagens que brilhantes autores conseguem criar e nos oferecer. Também podemos conhecer mais da história, de lugares e de pessoas. No período de isolamento social, encontramos algumas possibilidades gratuitas, que nos permitem embarcar em uma viagem dentro do conforto de nossa própria casa.

A Amazon oferece uma plataforma de e-books gratuitamente, sendo possível acessar a coleção por aqui: https://amzn.to/2wDqnWU.

Aqui oferecemos algumas áreas específicas:

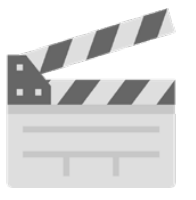

Para conhecer mais sobre Arte, Cinema e Fotografia, aqui você encontra 159 possibilidades:

\section{Acessar}

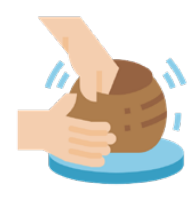

Para conhecer mais sobre Artesanato, Casa e Estilo de vida, aqui você encontra 17 possibilidades:

\section{Acessar}

Para conhecer mais sobre Autoajuda, aqui você encontra 75 possibilidades:

\section{Acessar}

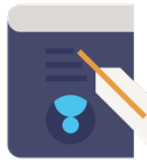

Para conhecer mais sobre Biografias e Histórias Reais, aqui você encontra 39 possibilidades:

Acessar 


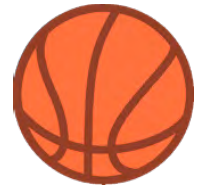

Para conhecer mais sobre Esportes e Lazer, aqui você encontra 13 possibilidades:

\section{Acessar}

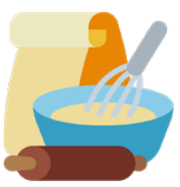

Para conhecer mais sobre Gastronomia e Culinária, aqui você encontra 627 possibilidades:

\section{Acessar}

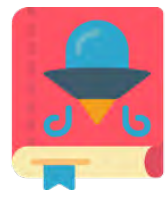

Para conhecer mais sobre Literatura e Ficção, aqui você encontra mais de 1000 possibilidades:

\section{Acessar}

Para conhecer mais sobre Religião e Espiritualidade, aqui você encontra mais de 103 possibilidades:

\section{Acessar}

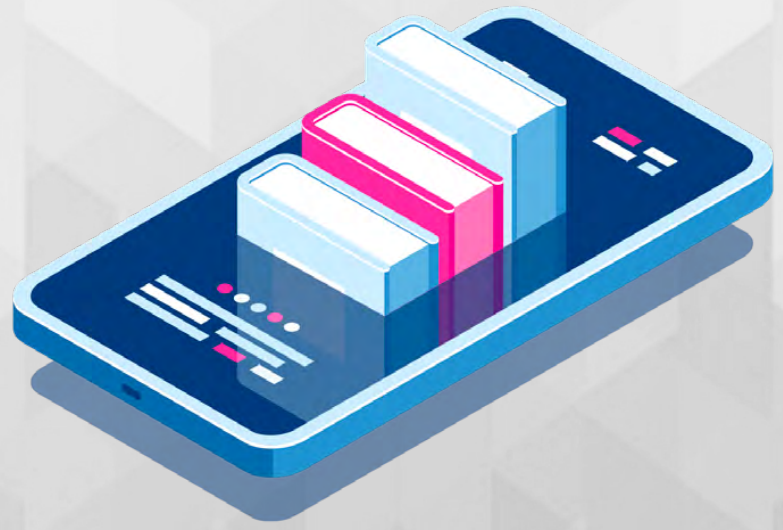

